\title{
Infestations and distribution of Rhopalosiphum padi (L.) on different varieties of barley and oats, effect of nitrogen fertilization and chemical control
}

\author{
SIRPA KURPPA ${ }^{1}$ and MARJA SUONPÄÄ ${ }^{2}$ \\ ${ }^{I}$ Institute of Plant Protection, Agricultural Research Centre, \\ SF-31600 Jokioinen \\ ${ }^{2}$ Department of Agricultural and Forest Zoology, University of Helsinki, \\ SF-00710 Helsinki
}

\begin{abstract}
Infestations of Rhopalosiphum padi were compared between common varieties grown at nitrogen levels of 50,100 and $150 \mathrm{~kg} / \mathrm{ha}$ in 1986 and 1988, and controlled with dimethoate in 1988 .

Colonization of the aphid was slightly quicker on oats than on barley. The highest peak inside field cages was 305 aphids and in the open field 74 aphids per plant. On barley, the number of aphids was highest on var. Pomo and var. Pokko, six-row type varieties with the longest growth period. On oats the number of aphids remained lower on var. Nasta, an early maturing variety with strong straw, than on other cultivars. Excessive nitrogen either increased or decreased the peak number of aphids per plant, depending on the variety and the year.

Over $40 \%$ of aphids on oats fed on the lower base of the plant at or under the soil surface. On barley, aphids lived slightly higher, $30 \%$ in the stem and $30 \%$ on leaves. Dimethoate spray controlled aphids on the top of the plant but not those on the base and lower leaves. Its efficacy against aphids on the upper stem and lower leaves on barley was decreased when an increased amount of nitrogen was used. The percentages of parasitized and diseased aphids decreased after the use of dimethoate.
\end{abstract}

Index words: barley, oat, Rhopalosiphum padi, bird cherry-oat aphid, varieties, nitrogen, distribution, chemical control, feeding site, dimethoate, parasitized, diseased

\section{Introduction}

Differences in Rhopalosiphum padi (L.) infestation between species of spring cereals and different varieties have been reported in Finland by MARKKULA and RoúkKa (1972) and RAUTAPÃÃ (1970) and elsewhere eg. Hsu and RoBInson (1963). The order of favourability to $R$. padi is known to be: barley, oats and wheat. In practice, wheat is damaged by 
$R$. padi much less than other spring cereals, and aphids on wheat seldom need to be controlled in Finland. On the basis of experiments in cages, RAUTAPÃA (1968) has described changes in yield components on cereals infested with $R$. padi.

Nitrogen fertilization is known to promote vegetative growth and the ability of spring cereals to tiller, thereby creating new sites for $R$. padi to feed on. By extending the period of vegetative development, excessive nitrogen extends the time for $R$. padi to multiply. It has been claimed that excessive nitrogen increases the need for aphid control.

The behaviour of aphids, especially their choice of feeding site, the stage of plant growth and biochemical interaction between aphids and plants have been shown to be important to the growth of aphid populations and to yield losses (Wratten 1978, LeATHER 1982, LesZCZynSKI 1985). WiKTELIUS (1987) has presented information about the feeding site of the bird cherry-oat aphid on spring barley. $R$. padi was found generally to favour the area of the plant that is under the soil surface.

Differences in the abundance and behaviour of $R$. padi on different varieties of spring barley and oats grown at different levels of nitrogen fertilization were studied in order to evaluate the effect of variety and nitrogen supply to the rate of increase of the aphid population and to the need for and the efficacy of chemical control. The experiment was performed in a year with a low expected $R$. padi population, 1986, and in a year with an exceptionally high expected aphid population, 1988, in Finland.

\section{Material and methods}

The field experiments, carried out at the Agricultural Research Centre in Jokioinen, included ten varieties of barley and oats (Fig. 2) (subplots) and three levels of nitrogen fertilization (50, 100 and $150 \mathrm{~kg}$ nitrogen/ha) (plots). The soil type was clay. Primary nitrogen fertilization was given as a Normal-Y fertilizer containing $10.1 \%$ of ammonium- $\mathrm{N}$ and
$5.9 \%$ of nitrate- $\mathrm{N}$. The excessive nitrogen to the levels of $100 \mathrm{~kg}$ and $150 \mathrm{~kg}$ nitrogen/ha was given as a salpetre fertilizer, called Oulun salpietari, containing $13.8 \%$ ammonium-N and $13.7 \%$ nitrate- $\mathrm{N}$. The number of replications was three, devided into randomized plots and randomized subplots, $12.5 \mathrm{~m}^{2}$ in size. Sowing dates were May the $19^{\text {th }}$ in 1986 and May the $16^{\text {th }}$ in 1988. Seedlings emerged from ten to fifteen days after sowing. No aphid control was needed in 1986. In 1988, the crop was sprayed on the 7th June, a week from the first peak of migration and the time when the first migrants were observed in the crop and 3 days from the second, final peak of migration. Dimethoate, $0.5 \mathrm{l} / \mathrm{ha}$ in 200 litres of water, was sprayed with a normal farm sprayer. At spraying, most varieties were at the 2-4 leaf stage. Half of each plot was sprayed, thus forming subsubplots of $6.25 \mathrm{~m}^{2}$.

In 1986, at the peak population, aphids were counted from 25 plants taken randomly from each subplot. In 1988 the population was observed more precisely. Migrants and exules of $R$. padi were first counted separately five days after the start of the spring migration, from a randomly chosen section of $0.5 \mathrm{~m}$ (about 25 plants) of a row, in the centre of each subsubplot. The second time, aphids were counted, one week after from the first count, from five $0.5 \mathrm{~m}$ long sections of rows (one of sections the same as first time). At the peak of the population (three weeks after first count), samples from one random row were taken to the laboratory and deepfrozen quickly, for observation later, in the autumn. In addition, during the first count, three plants were chosen from each unsprayed subsubplot, two with $1-5$ exules and a third with 5-10 exules per plant. These plants were covered with an aerated PVC cage to prevent the aphids from escaping and to keep their enemies out. The number of aphids from these plants were counted again two weeks later, and three weeks later (the peak of population) the plants were taken from the soil to the laboratory. During the last count made from samples of plant rows or single plants, apterae and 

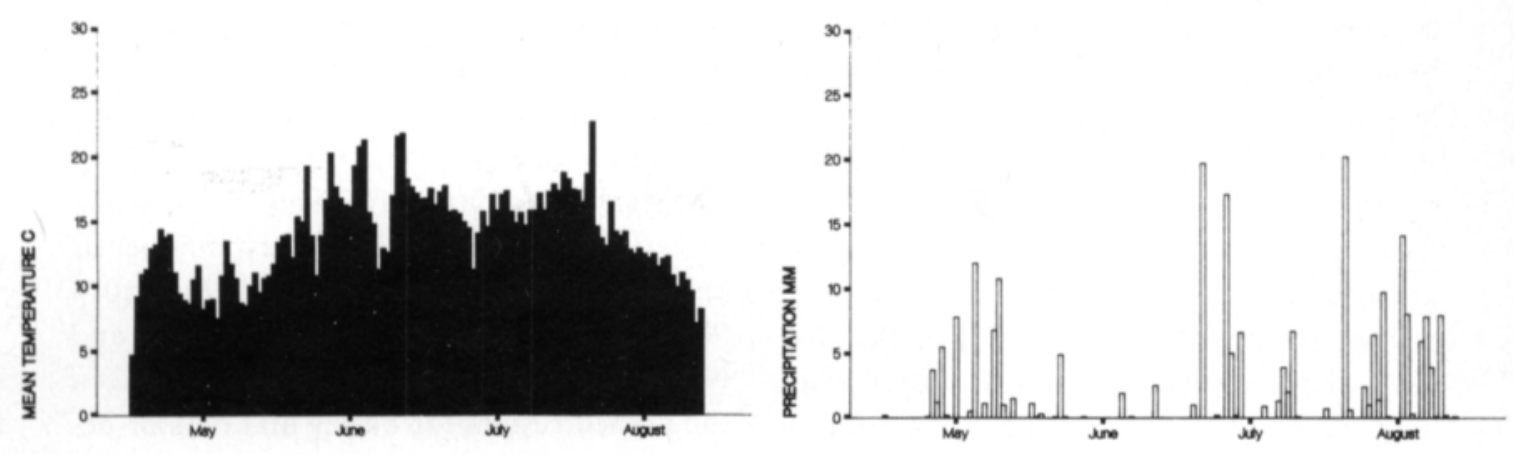

DATE

DATE

1986

1986
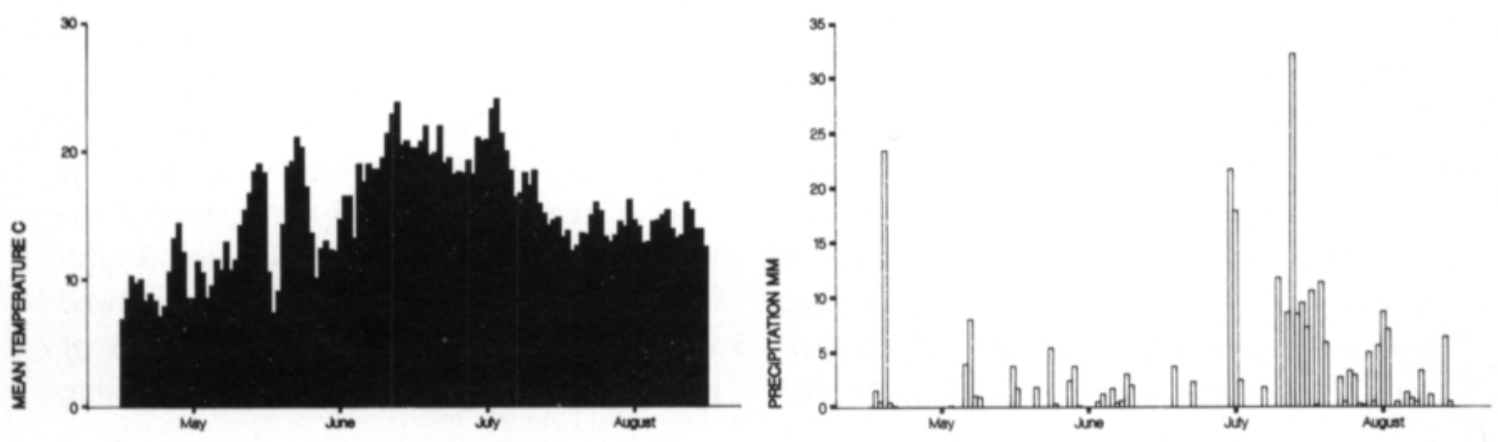

DATE

DATE

1988

1988

Fig. 1. Mean daily temperature (a, c) and daily precipitation (b, d) of the growing season in Jokioinen in 1986 and 1988 .

nymphs were counted separately from the base and upper stem from each leaf. The white area of the stem above the roots was considered to be the base of the plant. The height of the plant as well as the length of the flag leaf of the main shoot and of tillers were also recorded. During the sampling of the plants for the last count, number of coccinellids (larvae and adults) and syrphids (larvae) were counted. The number of parasitized and diseased aphids was recorded in the laboratory from samples.

Both experimental years were relatively warm. Daily precipitation and mean temperature are presented in Fig. 1.

\section{Results}

Colonization of plants by $R$. padi

In 1988, the first migrants were observed in the plants on the $1^{\text {st }}$ of May, three days from the first peak of the spring migration. (Spring migration peaked second time on the $5^{\text {th }}$ of May.) The total mean number of spring migrants that infested oats ( 2.25 aphids/plant) was double the number of migrants on barley $(1.0$ aphids/plant) $(\mathrm{P}<0.05)$. However, there was no difference between the incidence of infested plants of barley and oats. No significant differences were found between the 
number of spring migrants on the different barley and oats varieties, either. Incidence of migrants on all barley and oat varieties was significantly lower at the level of $50 \mathrm{~kg}$ nitrogen/ha than at the higher levels of nitrogen, the respective means being $17 \pm 6$ and $26 \pm 5 \%$ of plants, $\mathrm{P}<0.05$.

The number of first exules after the first days of spring migration was highest with the medium amount of nitrogen fertilization on oats (mean at the level of $100 \mathrm{~kg} / \mathrm{ha} 2.5$ aphids/plant, total mean 1.76 aphids/plant) $(\mathrm{P}<0.01)$. No other differences were found.

\section{Population growth on caged plants and in the open field}

The number of $R$. padi in caged plants in 1988 on barley and oats in the highest level of infestation increased very quickly, in three weeks to a maximum of 305 aphids per plant on var. Pokko (Fig. 2). There was a significant difference $(\mathrm{P}<0.01)$ in number of aphids between two groups of varieties. The group of varieties having the highest number of aphids included: Pomo (1), Pokko (3), Jo1439 (5), Eero (7), Puhti (11), Virma (Hja 75430) (14) and Titus (Tiitus) (16). The second group of varieties, which had the lowest number of aphids, included: Agneta (4), Arra (6), H1014 (9), Veli (12), Pol (13), Stil (Karhu) (19) and Nasta (20). No difference was found between the pooled results for barley and oats or between the pooled results for different levels of nitrogen fertilization. The peak number of aphids was, on average, 2.5 times higher in cages than in the surrounding open field.

In the open field in 1988, significant differences were found in aphid numbers per plant between varieties Pomo, Agneta and Ida at the lowest level of nitrogen fertilization (Fig. 3). But at higher amounts of nitrogen fertilization, the differences were not as clear. (Pomo and Agneta are six-rowed and Ida two-rowed varieties). On var. Ida only, the number of aphids increased continually with increasing

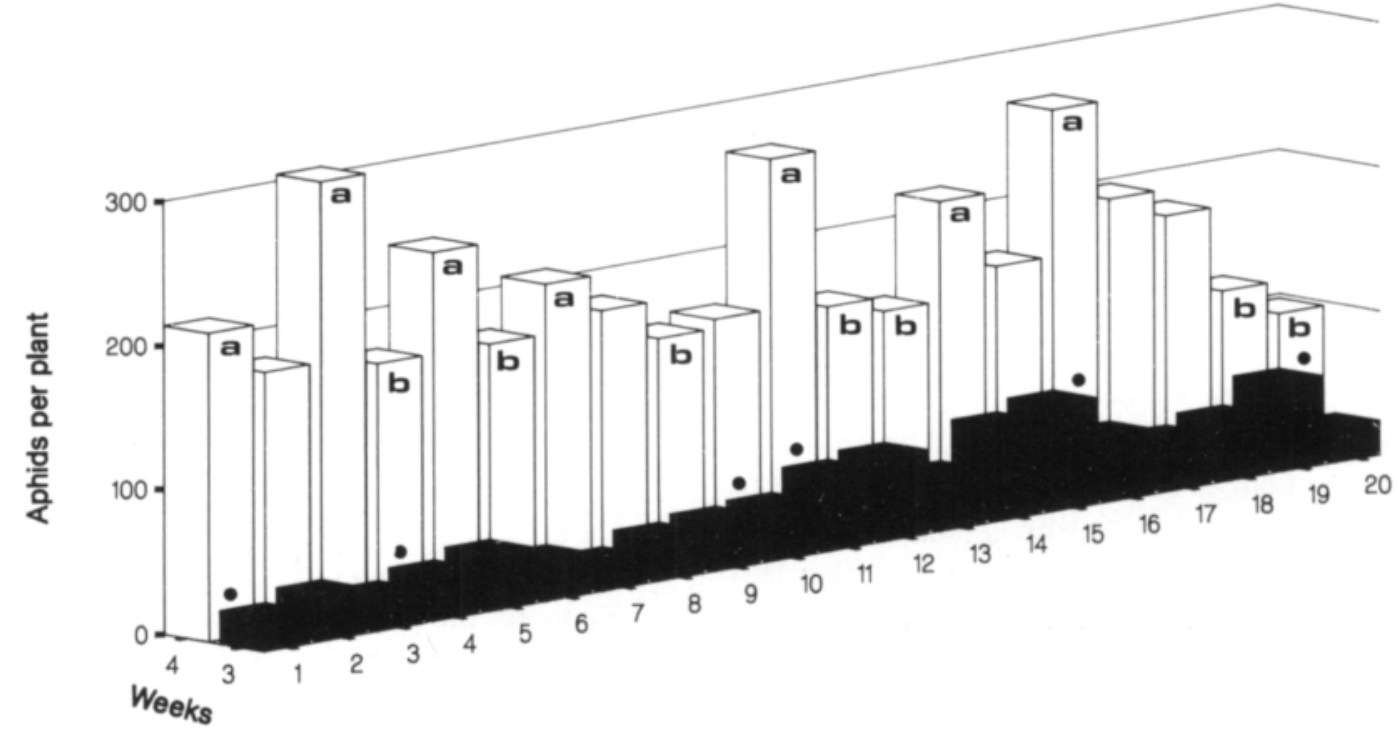

Cultivars barley (1-10), oat (11-20)

Fig. 2. Mean peak number of $R$. padi in plants grown in PVC cages. Primary infestation 5-10 aphids/plant. Dots indicate varieties taken for further observations in the open field. Barley cultivars: 1) Pomo, 2) Kalle, 3) Pokko, 4) Agneta, 5) Jo1439, 6) Arra, 7) Eero, 8) Pohto, 9) Norwegian H1014, 10) Ida. Oat cultivars: 11) Puhti, 12) Veli, 13) Pol, 14) Virma (Hja 75430), 15) WW 17593, 16) Titus (Tiitus), 17) Jo1057, 18) Vouti, 19) Stil (Karhu), 20) Nasta. Letters a and b indicate the two groups of varieties differing significantly $(\mathrm{P}<0.01)$ from each other. 
amounts of nitrogen (Fig. 3). With the same variety, the number of (subsidiary) tillers more than doubled, from 0.5 to 1.2 tillers/plant, as the nitrogen level was increased from $50 \mathrm{~kg} / \mathrm{ha}$ to $150 \mathrm{~kg} / \mathrm{ha}(\mathrm{P}<0.05)$. On var. Pomo, the number of tillers first increased from a mean of 1.3 to 1.8 , but it then decreased to 0.9 as the amount of nitrogen was increased from $50 \mathrm{~kg} / \mathrm{ha}$ to $100 \mathrm{~kg} / \mathrm{ha}$ and $150 \mathrm{~kg} / \mathrm{ha}$. On var. Agneta, however, the number of tillers remained unaffected. When the aphid numbers per shoot (main shoot + tillers) were compared only the number of aphids on cv. Pomo at the lowest nitrogen level (32.5) was significantly higher than the numbers of aphids on other varieties (mean 20.75 respectively) $(\mathrm{P}<0.01)$.

On oats, the number of aphids on var. Puhti tended to be higher than on var. Nasta (Fig. 3). The number of aphids per plant remained almost unaffected as the amount of nitrogen was increased, but the number of aphids per shoot (main shoot + tillers) de- creased slightly. With var. Puhti, the decrease was from 34.3 to 20.2 aphids/shoot between 50 and $100 \mathrm{~kg}$ nitrogen/ha, and with var. Titus (Tiitus) from 27.4 to 15.8 aphids/shoot between 50 and $150 \mathrm{~kg}$ nitrogen/ha $(\mathrm{P}<0.05)$. With Nasta, the number of aphids per shoot (mean 22.4) remained unaffected.

A similar tendency in the results for aphids on various varieties and with different levels of nitrogen was found in 1986, the year with a lower aphid population. On Pomo, the number of aphids (9.3/plant) was significantly higher than on other varieties at the lowest level of nitrogen (total mean 4.7 /plant) $(\mathrm{P}<0.05)$. At the level of $100 \mathrm{~kg} / \mathrm{ha}$ varieties Pomo, Pokko and Eero had significantly higher numbers of aphids (10.6, 9.2 and 8.7 aphids/plant) than other varieties: Kalle, Agneta and Arra (mean 3.3 aphids/plant) $(\mathrm{P}<0.05)$. The number of aphids on var. Ida was 7.6, on average. Already in 1986, the absolute maximum (14.2 aphids/plant), significantly higher than that of any other variety $(\mathrm{P}<0.05)$, was found on

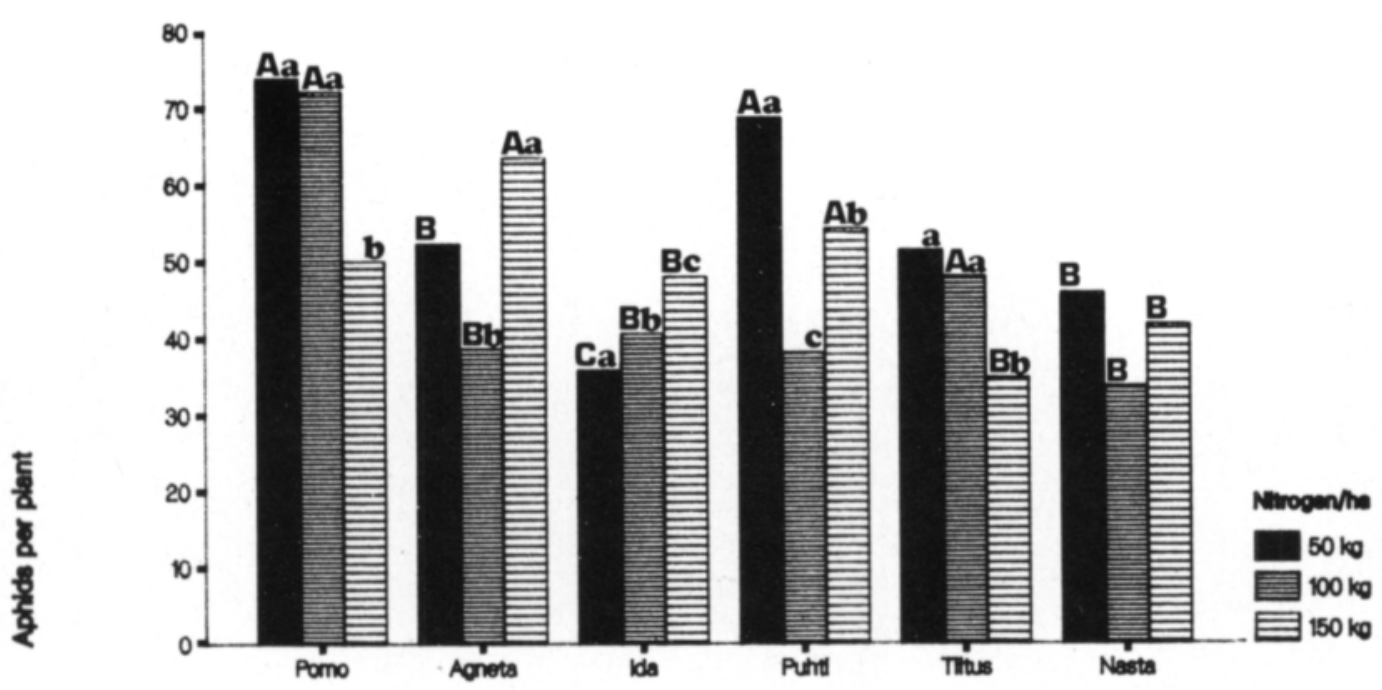

Cutturare

Fig. 3. Mean number of aphids per plant on different varieties of barley (Pomo, Agneta and Ida) and oats (Puhti, Titus and Nasta) fertilized with different levels of nitrogen in the field. Significant differences $(\mathrm{P}<0.05)$ between varieties at each level of nitrogen indicated by capitals, and significant differences $(\mathrm{P}<0.05)$ between levels of nitrogen within each variety indicated by small letters. 
Pokko at the highest level of nitrogen.

On oats in 1986, the mean number of aphids on var. Nasta at the two highest level of nitrogen (2.9 aphids/plant) and on var. Pol at the medium level of nitrogen (2.2 aphids/ plant) was significantly lower than on other varieties (mean 6.5 aphids/plant at nitrogen level of $100 \mathrm{~kg} / \mathrm{ha}$ and 5.9 aphids/plant at nitrogen level of $150 \mathrm{~kg} / \mathrm{ha})(\mathrm{P}<0.05)$.

\section{Distribution of $R$. padi on barley and oat plants}

On oats, $44 \%$ of aphids fed on the base of plant and $29 \%$ fed on the upper stem. On barley, $19 \%$ fed on the base, $32 \%$ on the stem and up to $34 \%$ on the lowest leaves (Table 1) (Fig. 4). There were only slight differences in the distribution between levels of nitrogen (Table 1) and varieties. The relative number of aphids on the strong and short straw of Ida $(27-41 \%)$ was significantly higher than that of Pomo (22-32 \%) $(P<0.05)$ Leaves of var. Pomo were broader and attracted relatively higher number of aphids.

In the comparison between the main shoot and tillers, significantly more aphids $(\mathrm{P}<0.05)$ were found on the upper stem of the main shoot than on the stem of tillers, and in tillers the number of aphids on leaves was significantly higher.

Table 1. Horisontal distribution of R. padi ( $\%$ of total population) on barley and oat plants treated with different levels of nitrogen fertilization.

\begin{tabular}{lccccccr}
\hline & \multicolumn{3}{c}{ Barley: main stem/tillers } & & \multicolumn{3}{c}{ Oat: main stem/tillers } \\
\cline { 2 - 3 } & $50 \mathrm{~N}$ & $100 \mathrm{~N}$ & $150 \mathrm{~N}$ & & $50 \mathrm{~N}$ & $100 \mathrm{~N}$ & $150 \mathrm{~N}$ \\
\hline Leaves 5-7 & $1 / 0$ & $2 / 1$ & $2 / 1$ & & $9 / 0$ & $9 / 1$ & $9 / 1$ \\
Leaves 3-4 & $11 / 17$ & $15 / 12$ & $14 / 13$ & & $6 / 27$ & $7 / 18$ & $7 / 17$ \\
Leaves 1-2 & $38 / 39$ & $31 / 38$ & $33 / 32$ & & $15 / 14$ & $8 / 13$ & $9 / 12$ \\
Stem & $35 / 21$ & $34 / 24$ & $26 / 34$ & & $29 / 22$ & $24 / 24$ & $33 / 25$ \\
Base & $15 / 23$ & $18 / 25$ & $25 / 20$ & & $41 / 37$ & $52 / 44$ & $42 / 45$ \\
\hline
\end{tabular}
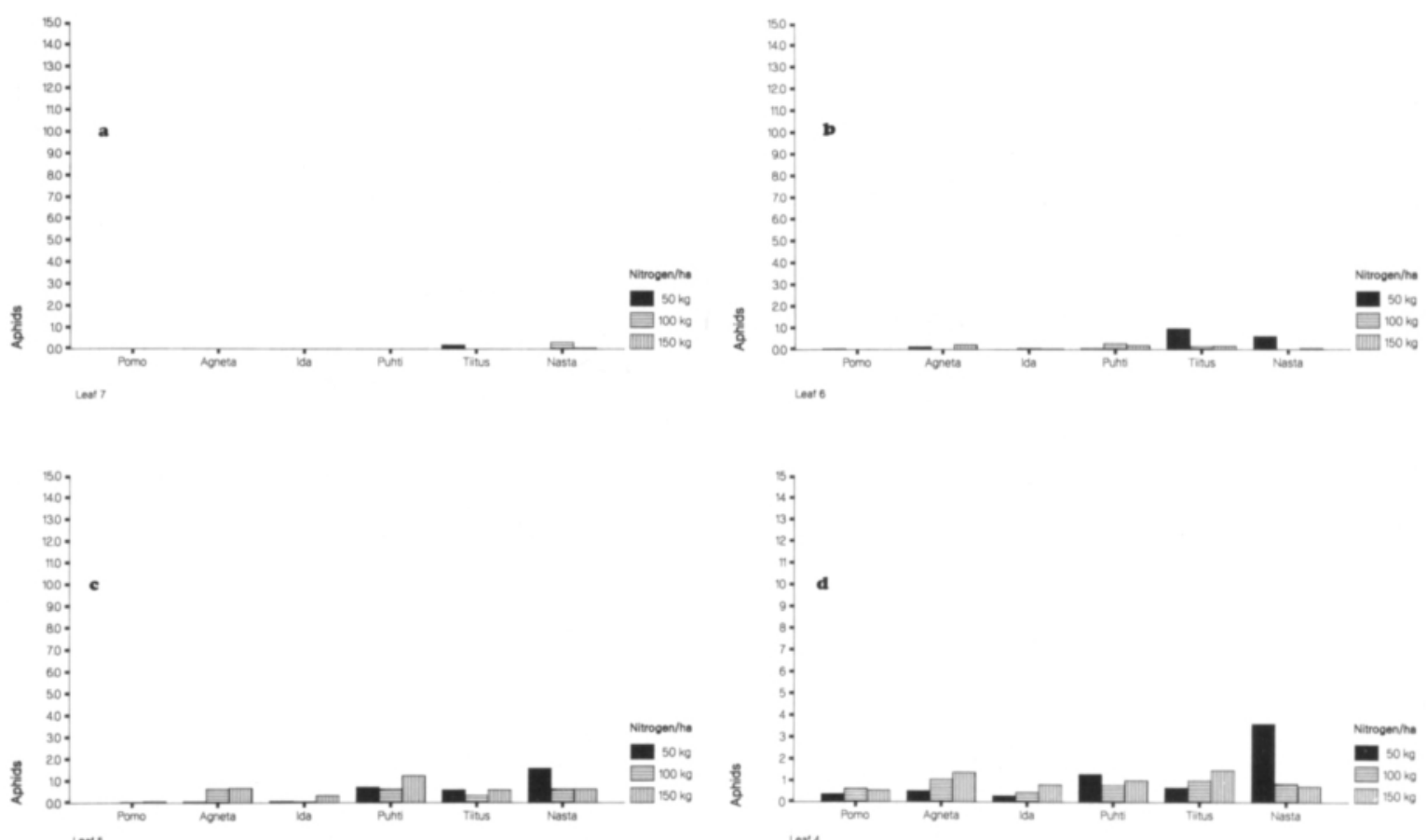

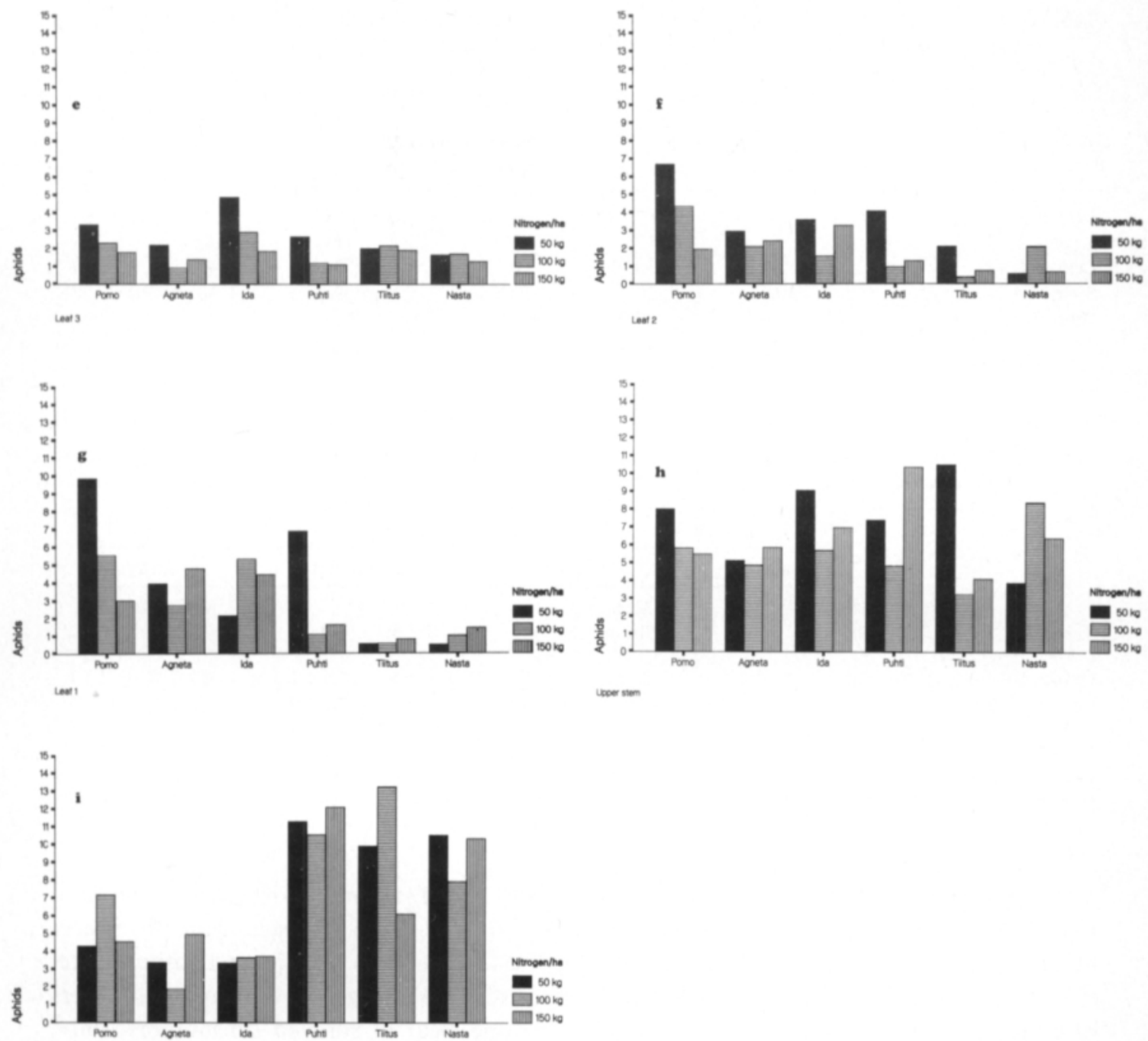

sons

Fig. 4. Number of $R$. padi on different parts of barley (Pomo, Agneta and Ida) and oats (Puhti, Titus and Nasta), a) 7 th upmost leaf, b) 6th leaf, c) 5th leaf, d) 4th leaf, e) 3th leaf, f) 2nd leaf, g) 1st leaf, h) upper stem, i) base of plant, at different levels of nitrogen of each variety.

\section{Parasitized and diseased aphids}

In the area without chemial control, the mean number of parasitized aphids was 0.36 / plant $(1.6 \%)$ on barley and 0.16 plant $(0.6 \%)$ on oats. On barley the mean number of diseased aphids was 4.2 plant (16.4\%). On oats, the respective figure was 0.45 plant $(1.5 \%)$ for var. Puhti, 2.38/plant (4.6\%) for var. Titus (Tiitus) and 3.73/plant (14.3\%) for var. Nasta. The difference between the varieties of oat was significant $(\mathrm{P}<0.05)$.
In dimethoate sprayed areas, the mean number of parasitized aphids on barley was $0.06(0.4 \%)$, and the mean number diseased aphids was $0.76(4.6 \%)$. The respective numbers on oats were $0.06(0.3 \%)$ and $0.7 /$ plant $(2.8 \%)$.

\section{Efficacy of dimethoate application}

The distribution of $R$. padi on plants greatly affected the efficacy of dimethoate. The ef- 
Table 2. Efficacy of a dimethoate spray $(\%)$ in decreasing the numbers of aphids on different horisontal areas of barley and oat plants at different levels of nitrogen application $(50,100$ and $150 \mathrm{~kg} \mathrm{~N} / \mathrm{ha})$.

\begin{tabular}{|c|c|c|c|c|c|c|}
\hline & \multicolumn{6}{|c|}{ Efficacy of dimethoate $\%$} \\
\hline & \multicolumn{3}{|c|}{ Barley } & \multicolumn{3}{|c|}{ Oat } \\
\hline & $50 \mathrm{~N}$ & $100 \mathrm{~N}$ & $150 \mathrm{~N}$ & $50 \mathrm{~N}$ & $100 \mathrm{~N}$ & $150 \mathrm{~N}$ \\
\hline Leaves $5-7$ & 94 & 95 & 94 & 93 & 94 & 94 \\
\hline Leaves $3-4$ & 69 & 45 & 42 & 71 & 33 & 66 \\
\hline Leaves $1-2$ & 84 & 30 & 0 & 30 & 40 & 30 \\
\hline Stem & 68 & 56 & 37 & 20 & 10 & 20 \\
\hline Base & 0 & 0 & 0 & 0 & 0 & 0 \\
\hline Total & 50 & 24 & 5 & 23 & 18 & 20 \\
\hline
\end{tabular}

Table 3. Horisontal distribution of R. padi ( $\%$ of total population) on barley and oat plants in the unsprayed and sprayed field.

\begin{tabular}{|c|c|c|c|c|c|c|c|c|}
\hline & \multicolumn{4}{|c|}{ Barley } & \multicolumn{4}{|c|}{ Oat } \\
\hline & \multicolumn{2}{|c|}{ Unsprayed } & \multicolumn{2}{|c|}{ Sprayed } & \multicolumn{2}{|c|}{ Unsprayed } & \multicolumn{2}{|c|}{ Sprayed } \\
\hline & $\begin{array}{l}\text { Main } \\
\text { Shoot }\end{array}$ & $\begin{array}{l}\text { Til- } \\
\text { lers }\end{array}$ & $\begin{array}{l}\text { Main } \\
\text { Shoot }\end{array}$ & $\begin{array}{l}\text { Til- } \\
\text { lers }\end{array}$ & $\begin{array}{l}\text { Main } \\
\text { Shoot }\end{array}$ & $\begin{array}{l}\text { Til- } \\
\text { lers }\end{array}$ & $\begin{array}{l}\text { Main } \\
\text { Shoot }\end{array}$ & $\begin{array}{l}\text { Til- } \\
\text { lers }\end{array}$ \\
\hline Leaves $5-7$ & $2 \pm 2$ & $1 \pm 1$ & $2 \pm 2$ & $1 \pm 1$ & $9 \pm 5$ & $1 \pm 1$ & $6 \pm 4$ & $1 \pm 1$ \\
\hline Leaves $3-4$ & $13 \pm 7$ & $14 \pm 3$ & $10 \pm 8$ & $12 \pm 5$ & $7 \pm 2$ & $21 \pm 9$ & $4 \pm 2$ & $11 \pm 7$ \\
\hline Leaves $1-2$ & $34 \pm 10$ & $36 \pm 4$ & $25 \pm 7$ & $29 \pm 11$ & $10 \pm 7$ & $13 \pm 8$ & $10 \pm 5$ & $13 \pm 6$ \\
\hline Stem & $32 \pm 8$ & $26 \pm 7$ & $20 \pm 10$ & $16 \pm 9$ & $29 \pm 10$ & $24 \pm 6$ & $33 \pm 11$ & $20 \pm 9$ \\
\hline Base & $19 \pm 9$ & $22 \pm 5$ & $43 \pm 14$ & $45 \pm 11$ & $44 \pm 11$ & $42 \pm 12$ & $47 \pm 9$ & $55 \pm 9$ \\
\hline
\end{tabular}

ficacy was excellent against aphids at the top of the plant, but nonexistent against the aphids feeding on the base (Table 2). This result was clearly reflected in the total efficacy of dimethoate spray, which on barley, at the lowest level of nitrogen fertilization, was reasonable but on oats was unacceptable. Increased nitrogen affected the efficacy of dimethoate on barley (Table 2), which was due to the decreased efficacy against aphids on the upper stem and lower leaves. On sprayed plants, aphids concentrated more on the base and the lowest leaves (Table 3). On one sprayed variety, Pomo, up to $71 \%$ of aphids remained on the base of plant.

\section{Correlations between $R$. padi population growth and plant growth}

The number of tillers of oats was decreased by the aphids feeding the base of plant, regression equation: number of tillers $=2.16-$
$0.017 \pm 0.007 \times$ number of aphids in the base, $\mathrm{R}^{2}=0.26, \mathrm{P}<0.05$. The significant differences $(\mathrm{P}<0.01)$ between varieties and positive effect of excessive nitrogen in the number of tillers became clear in sprayed subsubplots, only. This was mainly due to an unusual result obtained with var. Puhti, where spraying caused a decrease in the mean number of tillers/plant; at the two lowest levels of nitrogen the decrease was from 1.0 and 0.88 to 0.30 and 0.41 (secondary) tillers/plant $(\mathrm{P}<0.01)$. On barley aphids had no effect on number of tillers. Spraying did not affect significantly the number of tillers of barley, either.

In the cages, a slight positive correlation was found between adults and nymphs on the base and upper parts of tillers and the height of the main shoot $(\mathrm{r}=0.17, \mathrm{P}<0.01)$ and the length of the flag leaf in centimetres $(r=0.175, P<0.01)$. In the field a positive correlation was found between the number of aphids on the base of tillers, or the num- 
ber of aphids on the stem, and the height of the tiller (aphids on base $r=0.06$, aphids on stem $\mathrm{r}=0.105, \mathrm{P}<0.001)$. Similarly, a slight positive correlation was found between the number of aphids on the base or the stem of oats $(r=0.09, P<0.001)$ or aphids in the whole plant of barley $(r=0.16, P<0.01)$ and the length of flag leaf. A negative correlation was found between the number of aphids on the second to the fourth leaf and the height of the tiller of barley and oats (barley $r=-0.096$, $\mathrm{P}<0.05$, oats $\mathrm{r}=-0.176, \mathrm{P}<0.001)$ and the length of flag leaf of oats $(r=-0.066$, $\mathrm{P}<0.05)$. The tiller height of both cereal species, mean $33.9 \mathrm{~cm}$ for barley and $31.4 \mathrm{~cm}$ for oats, was not affected by excessive nitrogen. The length of the flag leaf of barley, mean $13.9 \mathrm{~cm}$, was increased (from 13 to $15 \mathrm{~cm}$ ) by excessive nitrogen, but the mean length of the flag leaf of oats, $16.8 \mathrm{~cm}$, was not affected. Spraying had no significant effect on these parameters.

In the unsprayed subsubplots, there was a negative correlation between the yield of barley and oat varieties $(\mathrm{kg} / \mathrm{ha})$ and the number of aphids on the lower base of plants (barley $\mathrm{r}=-0.33, \mathrm{P}<0.05$, regression equation: yield $=4774-16 \pm 5 \times$ no of aphids on the base, oats $\mathrm{r}=-0.24, \mathrm{P}<0.01$, regression equation: yield $=4091-32 \pm 11 \times$ no of aphids on the base). The mean yield of barley varieties Pomo, Agneta and Ida was 4445 kg/ha (unsprayed), and increased significantly with the increase of nitrogen fertilization from $50 \mathrm{~kg}$ / ha to $100 \mathrm{~kg} / \mathrm{ha}(\mathrm{P}<0.01)$. The mean yield of oat varieties was $3320 \mathrm{~kg} / \mathrm{ha}$ (unsprayed), and it also increased with an increased amount of nitrogen $(\mathrm{P}<0.05)$.

On barley, a variable yield increase $-9 \%$ on Pomo and $4 \%$ on Agneta and $3 \%$ on Ida - was obtained by a dimethoate spray at the lowest level of nitrogen, but at highest level of nitrogen, dimethoate caused a greater yield loss, with Pomo $9.4 \%$ and Ida $6.6 \%$. On oats, the mean yield increase due to dimethoate spraying was $11.6 \%$, but the effect of dimethoate was highly variable (from slight negative to a positive effect of $50 \%$ ).

\section{Discussion}

A higher incidence of migrants at the higher levels of nitrogen referred to the effect of an intense green colour of an excessively fertilized crop. But, the observation that a higher number of spring migrants landed on oats than on barley was a surprise, on the basis of information about the poor ability of $R$. padi to select host plant presented by ÅHMAN et al. (1985). However, this result agrees with the findings reported by Weibull (1987). The higher number of exule nymphs at the medium level of nitrogen was partly resulted from incidence of migrants, but might also indicate some minor changes in the biochemical balance of free and structural amino acids in plants (Niraz et al. 1985).

The unstricted population growth of $R$. padi in cages was comparable to the results presented by RAUTAPĀÃ (1968). Great difference between population growth in cages and the open field may partially result from caging out facultative predators such as carabid beetles, and of the specific enemies coccinellids, the number of which increased explosively until the end of June in the open field. The numbers of syrphids and hymenopterid parasites, on the contrary, were very low. Another possible reason for the excessive population growth could be a great improvement in conditions inside cages, such as increased humidity.

The differences in the number of $R$. padi between barley varieties were in agreement in the two experimental years, as were those for cages and the open field. The differences were obvious in a year of lower aphid population, but during higher pressure resulting from a larger population, the differences were not so clear. During an aphid outbreak, there is no way chemical control can be avoided by the selection of a specific commercial variety. On oats, which is favoured more by $R$. padi, the differences between cultivars seem to be minor in the field, even at a low level of aphid infestation.

The decrease in the number of aphids on 
oats at the higher levels of nitrogen is in agreement with the results of WeIBULL (1987). He reported that extra nitrogen fertilization resulted in a decrease in the total content of free amino acids in oats at the beginning of stem elongation. Weibull increased the nitrogen level from 50 to $100 \mathrm{~kg} / \mathrm{ha}$ and had one variety of barley and oats. Differences in the reactions of different varieties are thus possible. Another way nitrogen could have an effect on the aphid population would be by causing changes in the number of tillers. Barley seemed to be sensitive to this. In our experiment, unfortunately, it was not evaluated how much nitrogen was actually used by plants in the prevailing dry conditions.

The feeding area of $R$. padi was shown to be an important factor in the efficacy of pest control application; this finding partly explains many of the complaints about the efficacy of dimethoate presented in 1988. The phytotoxic effect of dimethoate on barley became obvious, as the efficacy at highest level of nitrogen was minimal. A slightly earlier application, better directed at migrating aphids, might have given better efficacy. The decreased tillering of var. Puhti in the area where aphids became controlled on the upper parts of plant indicates a change in apical dominance. Feeding on the upper area of the main shoot possibly resulted in a decrease of apical dominance there, and tillering was promoted. When controled, feeding stopped right at the beginning, apical dominance remained effective. This issue has been discussed by HARRIS (1974).

The percentage of parasitized aphids was low, and the percentage of diseased aphids fairly high compared to counts made in Sweden in 1980-83 (WiкTElius and Еквом 1985). The decrease in parasitized aphids due to dimethoate spraying was expected, but the decrease in the percentage of diseased aphids was more surprising. However, the effect of insecticides in eliminating sensitivity to disease in the rape blossom beetle, Meligethes aeneus F., has been discussed by HOKKANEN et al.
(1988). The highest proportion of diseased aphids was found in oats on a variety that generally supported the lowest populations of $R$. padi. This might be an indication of weakened condition and induced sensitivity of aphids on that variety. Differences in disease abundance may also indicate differences in humidity within the crop, crop structure affecting the penetration of fungus spores or minor differences in facultative microflora on the plant surface.

Vigorous plants had the highest number of $R$. padi, especially in cages, as also reported by HoNEK (1985). However, there was a slight negative correlation between the height of plants and the length of the flag leaf of oats and the number of aphids on leaves in the middle part of plant; similar results were reported for winter wheat by HavLicKova (1984). The correlations referred to the behaviour of aphids in the plant when the population peak is approaching, but for practice the results had just a value of curiosity. Aphids on the base of plants seemed to be important in connection to yield loss, the mechanism most possibly being a decrease in the number of grains. As the plant becomes older and the base becomes dry, $R$. padi typically moves to higher parts of plant. There $R$. padi could be expected to affect grain quality, grain weight and protein content, as reported with Metopolophium dirhodum Wlk. (WRATTEN 1978). These changes were demonstrated by RAUTAPÄÄ (1968) in caged plants, but at a very high population level. After moving to upper parts of plants, $R$. padi in the field very quickly started the summer migration. Injuries on plants in this stage last a few days only, and are certainly of minor importance.

The effects attained by changing between available Finnish barley or oat varieties or decreasing the amount of nitrogen fertilizer proved to be very complex. The differences discussed here are valid for explaining variability in population growth and the results of pest control after the fact, but difficult to incorporate as part of practical pest control. 


\section{References}

Harris, P. 1974. A possible explanation of plant yield increases following insect damage. Agro-Ecosystems 1: 219-225.

HavličKovÁ, H. 1984. The growth of emerging wheat plants infested with aphids. Ochr. Rostl. 20 (2): $131-136$.

Hokkanen, H., Husberg, G.-B. \& Söder blom, M. 1988. Natural enemy conservation for the integrated control of the rape blossom beetle Meligethes aeneus $\mathrm{F}$. Ann. Agric. Fenn. 27: 281-294.

HoNĚK, A. 1985. Plant density and abundance of cereal aphids (Hom., Aphidina). Z. Angew. Ent. 100: 309-316.

Hsu, S.-J. \& Robinson, A.G. 1963. Further studies on resistance of barley varieties to the aphid Rhopalosiphum padi (L.). Can. J. Plant Sci. 43: 343-348.

LEATHER, S.R. 1982. Preliminary studies on the effect of host age and aphid generation on the reproduction and survival of the bird cherry-oat aphid, Rhopalosiphum padi (L.). Ann. Agric. Fenn. 21: 13-19.

LeszcZYŃSKı, B. 1985. Changes in phenols content and metabolism in leaves of susceptible and resistant winter wheat cultivars infested by Rhopalosiphum padi (L.) (Hom., Aphididae). Z. Angew. Ent. 100: 343348.

MARKKULA, M. \& RoUKKA, K. 1972. Resistance of cereals to the aphids Rhopalosiphum padi (L.) and Macrosiphum avenae (F.) and fecundity of these aphids on Graminae, Cyperaceae and Juncaceae. Ann. Agric. Fenn. 11: 417-423.

\section{SELOSTUS}

\section{Typpilannoituksen ja kemiallisen torjunnan vaikutukset tuomikirvojen esiintymiseen ja tuhoihin eri ohra- ja kauralajikkeissa}

\author{
Sirpa Kurppa and Marja Suonpää
}

Tuomikirvan esiintymistä verrattiin tavallisimpien Suomessa viljeltyjen kaura- ja ohralajikkeiden ja muutamien jalostuslinjojen vălillă vuosina 1986 ja 1988 . Samalla tutkittiin typpilannoituksen vaikutusta kirvoihin. Typpimaaărăt olivat kylvőn yhteydessä annettuina $50 \mathrm{~kg}, 100 \mathrm{~kg}$ ja $150 \mathrm{~kg} /$ ha puhdasta typpeä.

Kevaaăllă muuttavat kirvat levittăytyivăt hieman tasaisemmin runsaasti typpilannoitetuissa kaura- ja ohrakas-
Niraz, S., Leszczyński, B., Ciepiela, A., Urbańska, A. \& WARCHOK, J. 1985. Biochemical aspects of winter wheat resistance to aphids. Insect Sci. Application 6: 253-257.

RAUtAPĀA, J. 1968. Changes in the yield and protein quantity of oat caused by Rhopalosiphum padi (L.) (Hom., Aphididae). Ann. Agric. Fenn. 7: 95-104.

- 1970. Preference of cereal aphids for various cereal varieties and species of Graminae, Juncaceae and Cyperaceae. Ann. Agric. Fenn. 9: 267-277.

Weibull, J. 1987. Seasonal changes in the free amino acids of oat and barley phloem sap in relation to plant growth stage and growth of Rhopalosiphum padi. Ann. Appl. Biol. 111: 729-737.

WiкTELIUS, S. 1987. Distribution of Rhopalosiphum padi (Homoptera: Aphididae) on spring barley plants. Ann. Appl. Biol. 110: 1-7.

- \& Еквом, В. 1985. Aphids in spring sown cereals in central Sweden. Abundance and distribution 19801983. Z. Angew. Ent. 100: 8-16.

WrATtEN, S.D. 1978. Effects of feeding position of the aphids Sitobion avenae and Metopolophium dirhodum on wheat yield and quality. Ann. Appl. Biol. 90: $11-20$.

Åhman, I., Weibull, J. \& Pettersson, J. 1985. The role of plant size and density for host finding in Rhopalosiphum padi (L.) (Hem.: Aphididae). Swed. J. Agric. Res. 15: 19-24.

Ms received August 19, 1989 vustoissa ja jäivăt runsaslukuisempina kauraan kuin ohraan.

Ohrista Pomon ja Pokon kirvamäărăt nousivat kaikkein suurimmiksi. Kun kirvoja oli yleisesti vähän, kirvamäărät lisăăntyivăt merkitsevăsti typpiannosta lisăttăessă. Vuonna 1986, 50 kg - 100 kg/ha typpiannoksen lisäyksen seurauksena lisảăntyivăt myős Eeron kirvamäărăt jyrkästi. Kallen, Agnetan ja Arran kirvamăărăt olivat alim- 
milla typpilannoitustasoilla $(50 \mathrm{~kg}-100 \mathrm{~kg} / \mathrm{ha})$ muita merkitsevăsti alhaisemmat. Tuomikirvan massaesiintymăvuonna, 1988, kirvamäărăt ylittivăt alimmillakin typpilannoitustasoilla selvăsti torjunnan kynnysarvot, ja kirvamăărăt lisăăntyivăt typpilannoituksen lisäyksen myötă tasaisesti ainoastaan Ida-lajikkeessa. Muiden lajikkeiden kirvamaaărăt jopa laskivat typpilannoitusta lisăttäessă.

Kauralajikkeiden văliset kirvamäärien erot kasvustossa olivat hyvin pienet. Ainoastaan Nastan kirvamäärät jăivăt, varsinkin runsaimpia typpiannoksia kăytettăessä, muita alhaisemmiksi. Versoa kohden laskettu kirvamảäră aleni yleisesti typpilannoitusmäăràă lisăttăessă.

Kaurassa yli $40 \%$ tuomikirvoista oli asettunut tyven valkeaan osaan, siis maanpinnan rajaan tai päăllimmäisten maakokkareiden tasalle. Ohran tuomikirvoista $25 \%$ oli asettunut tyveen, noin $30 \%$ korteen ja noin $30 \%$ alimmille lehdille. Myős lajikkeiden vălillă, erityisesti ohrissa, havaittiin lieviă eroja.

Kirvojen sijoittuminen viljakasvissa vaikutti ratkaisevasti dimetoaatin tehoon. Tehoa tutkittiin kuivana ja lămpimănă kasvukautena 1988. Kasvustossa dimetoaatilla ei havaittu lainkaan tehoa kasvien tyvessä oleviin kirvoihin.
Torjunnan kokonaisteho jäi ohrissa parhaimmillaan noin $50 \%$ :iin ja kauroissa vain noin $25 \%$ :iin. Teho ohrissa heikkeni ennestaaăn kun typpiannosta lisăttiin, 100 kg/ha typpiannosta kăytettäessă teho oli $30 \%$ ja $150 \mathrm{~kg} /$ ha typpiannosta käytettăessă vain $5 \%$. Kauran ruiskutusten tehoon typpilannoituksella ei ollut vaikutusta, mutta kirvatorjunta văhensi lajikkeen Puhti versontaa alimpia typpilannoitusmäăriă kăytettăessă.

Dimetoaatin havaittiin văhentäneen kirvojen loisia ja myös sienitauteihin siarastuneiden kirvojen mäăriä. Sienitautisten kirvojen yleisyys vaihteli myös kauralajikkeittain ollen runsain kirvoille ilmeisen epäedullisimmassa lajikkeessa, Nastassa.

Lajikkeiden ja typpimäărän merkitys osoittautui kovin monitahoiseksi ja vaihteli vuosittain. Nãyttäă siltă, ettă viljan typpilannoituksen tehokkuudella ja nykyisin viljelyssă olevien lajikkeiden vălisellă valinnalla on kăytănnőssă hyvin vaikea suunnitellusti vaikuttaa kirvatorjunnan tarpeeseen ja kirvatorjunnan tehoon. Kirvapopulaatioiden kasvun ja torjuntatulosten vaihteluita lajikevalinnalla ja typpimaaărän vaihtelulla voidaan kylläkin jălkikăteen selittăă. 